\title{
COMPARISON OF A COMMERCIAL ENZYME IMMUNOASSAY WITH PLAQUE REDUCTION NEUTRALIZATION FOR MATERNAL AND INFANT MEASLES ANTIBODY MEASUREMENT
}

\author{
Guilherme GONÇALVES (1), Felicity CUTTS (2), Timothy FORSEY (3) \& Helena Rebelo ANDRADE (1)
}

\begin{abstract}
SUMMARY
The most practicable assay for measurement of measles $\mathrm{IgG}(\mathrm{mIgG})$ in large numbers of sera is an enzyme immunoassay (EIA). To assess how EIA results would agree with those by the gold standard method of plaque reduction neutralization (PRN) we compared the results from the two methods in 43 pairs of maternal and umbilical cord sera, and sera from the corresponding infants when aged $11-14$ months. In maternal-cord sera, the differences between mean antibody levels by EIA or PRN were not statistically significant, though in individual sera, differences could be large. However, agreement was less good for infants sera, in which levels of $\mathrm{mIgG}$ were very low. The conclusions of a study of transplacental transport of $\mathrm{mIgG}$ would not be affected by the use of either technique. When studying waning immunity in infants, PRN should be the method of choice, while results from studies using EIA should be interpreted with caution.
\end{abstract}

KEYWORDS: Measles; IgG; Enzyme immunoassay; Plaque neutralization.

\section{INTRODUCTION}

Measles-specific IgG ( $\mathrm{mIgG}$ ) may be measured by a variety of methods that differ in their sensitivity and specificity ${ }^{13}$. The plaque reduction neutralization (PRN) assay is considered to be the "gold standard" because of its high sensitivity and specificity ${ }^{27}$. PRN assays can detect very low levels of antibody, and evidence showed that antibody titers less than $200 \mathrm{mIU} / \mathrm{ml}$ are not fully protective against clinical disease ${ }^{9}$. This assay is, however, too demanding of time and resources to use to screen large numbers of sera.

Commercial enzyme immunoassay (EIA) tests are widely available, and their relative ease of execution make them attractive for field studies ${ }^{10,30}$. EIA is generally more sensitive than HI and complement fixation (CF) tests ${ }^{27}$. Many studies have shown that seropositivity in EIA assays correlates with protection from clinical measles $^{20,26,31}$, but that seronegatives are not necessarily susceptible, as only a small proportion of seronegative individuals acquired measles disease in these studies. The specificity of EIA assays also varies between laboratories and some assays have correlated poorly with the results of neutralization tests, particularly for the measurement of low levels of maternally derived measles antibody in 4-6 month old infants ${ }^{28,29}$.

Though the PRN assay is the "gold standard", EIA assays are quicker and cheaper to perform, and require only very small volumes of sera which is an advantage in studies of young infants ${ }^{12}$. Unfortunately, commercially available kits of EIA differ in terms of their sensitivity and specificity ${ }^{21,27}$, which poses an additional problem. The use of reference sera, calibrated against the International Standard for anti-measles serum (IS) ${ }^{17}$, in parallel with the sera under study, has been recommended by the Expanded Programme on Immunization (EPI) as a way of reducing variation in results between different tests and different laboratories ${ }^{12}$. Nevertheless, even with the use of the IS, problems of comparability between results from different methods still arise $\mathrm{e}^{4}$. Very few studies using EIA have used the IS or reported the results in milli-international units per millilitre $(\mathrm{mIU} / \mathrm{ml})^{19,21,22}$.

We planned a study on transplacental transport efficiency of measles-specific IgG in over one thousand pairs of samples of maternal and umbilical cord sera. To assess the consequences of using an EIA assay, we compared the results obtained by EIA with those from PRN on a subsample of sera. To assess how the differences between the assays might affect the conclusions from different types of epidemiological study, we also used EIA and PRN to measure mIgG in the sera of infants when they reached 1114 months of age (the age for routine measles vaccination in many industrialised countries).

(1) Instituto Nacional de Saúde Dr Ricardo Jorge, Portugal

(2) London School of Hygiene and Tropical Medicine, UK

(3) National Institute for Biological Standards and Control, UK

Correspondence to: Guilherme Gonçalves, Instituto Nacional de Saúde Dr Ricardo Jorge, Delegação no Porto, Largo $1^{\circ}$ de Dezembro, 4000 Porto, Portugal. (Fax: 351-2-2005323) 
GONÇALVES, G.; CUTTS, F.; FORSEY, T. \& ANDRADE, H.R. - Comparison of a commercial enzyme immunoassay with plaque reduction neutralization for maternal and infant measles antibody measurement. Rev. Inst. Med. trop. S. Paulo, 41 (1): 21-26, 1999.

\section{METHODS}

After obtaining informed consent from women, venous blood samples were collected from the mother and the umbilical cord. Follow-up samples were obtained from 43 infants when they reached 11-14 months of age. For these 43 infants, sera from maternal and cord blood, and the corresponding sera from infants were tested by both EIA and PRN.

Levels of $\mathrm{mIgG}$ were measured using a commercial enzyme immunoassay (14458 Measles Virus IgG EIA, Diagnostica, Merck) at the Virology Department of the National Institute of Health (INSA), in Lisbon. A Portuguese standard serum $(\mathrm{AH})$ was calibrated against the International Standard for anti-measles serum ${ }^{17,19}$, and then used in each EIA, thus making it possible to report the results in mIU/ $\mathrm{ml}^{19}$. In the calibration study, the AH standard serum was used in the dilutions $1 / 50$ to $1 / 12800$, in each EIA plate. The optical density (OD) response values were plotted to draw a curve relating the logarithm of the dilution (or the concentration in $\mathrm{mIU} / \mathrm{ml}$ ) with OD. A Basic computer programme (written by Prof Maia, University of Oporto) tested the fitting of a logistic curve to the observed OD values by dilution (or the concentration) fitted as natural logs. The fitting was always excellent with $\mathrm{R}^{2}$ values close to 0.999 for all forty plates that were used (minimum of 0.99857 ). The programme also derived the parameters of the logistic curve with the best fit, which were used in an Epi-Info programme ${ }^{16}$ which converted values of OD into $\mathrm{mIU} / \mathrm{ml}$ for all study sera tested.

The same sera were also tested by plaque reduction neutralization (PRN), following published procedures ${ }^{1,17,24}$ at the National Institute for Biological Standards and Control (NIBSC), U.K.. Results were expressed in $\mathrm{mIU} / \mathrm{ml}$.

Scatter plots were produced of the values obtained by the two methods. The differences between the two methods were then plotted against their mean ${ }^{7,18}$. Because the differences in $\mathrm{mIU} / \mathrm{ml}$ between the two methods increased as the concentration increased, the following further analysis was conducted on log-transformed concentrations.

The mean difference between the two methods, termed the "bias" of the EIA technique relative to PRN, was computed. The respective 95\% "limits of agreement" include the difference between single measurements on the same serum by the two methods with $95 \%$ probability3,6,7. The antilog of the bias represents the "proportional bias" between the two methods and the antilogs of the $95 \%$ limits of agreement gave us the range of "proportional agreement" (for individual measurements) between EIA and PRN ${ }^{3,5,6}$. The standard error and $95 \%$ confidence interval of the bias were also computed and a paired t-test was performed to examine the hypothesis of zero bias (or proportional bias equal to 1).

To assess the effect of using EIA rather than PRN assays in the study of transplacental concentration of measles antibody, a regression model of cord level on maternal level, with measles IgG measurement method as a dummy variable, was fitted to the data in order to test if, in the EIA and PRN groups, the slopes were parallel, the intercepts were equal and finally if the models were coincident ${ }^{23}$.
One-way analysis of variance was used to compare transplacental concentration ratios computed with the data from EIA and PRN methods.

Maternal antibody levels of 40-99 $\mathrm{mIU} / \mathrm{ml}$ may delay the antibody response to measles vaccination, while levels of $100 \mathrm{mIU}$ or more greatly reduce the response to standard titre vaccines ${ }^{25}$. Thus, for infants sera, we assessed the sensitivity and specificity of EIA versus PRN using either 40 or $100 \mathrm{mIU} / \mathrm{ml}$ as the cut-off for seropositivity.

\section{RESULTS}

\section{Measles antibody levels}

The geometric mean concentrations of measles antibody levels were very similar by both assays (Table 1). Levels were higher in umbilical cord than maternal sera, as expected ${ }^{4}$.

TABLE 1

Measles $\operatorname{IgG}(\mathrm{mIgG})$ geometric mean concentration (GMC) in maternal and corresponding umbilical cord sera $(n=43)$ measured by enzyme immunoassay (EIA) and plaque reduction neutralization (PRN)

\begin{tabular}{|c|c|c|}
\hline \multicolumn{3}{|l|}{ Type of sera } \\
\hline GMC (Log) & \multicolumn{2}{|c|}{ Technique used to measure $\mathrm{mIg}$} \\
\hline $\mathrm{GMC}(\mathrm{mIU} / \mathrm{ml})$ & EIA & PRN \\
\hline \multicolumn{3}{|l|}{ Maternal sera } \\
\hline $\log (s d) *$ & $7.04(0.98)$ & $7.05(1.28)$ \\
\hline $\mathrm{mIU} / \mathrm{ml} \dagger$ & 1145 & 1153 \\
\hline \multicolumn{3}{|l|}{ Umbilical cord sera } \\
\hline $\log (s d) *$ & $7.34(1.15)$ & $7.40(1.31)$ \\
\hline $\mathrm{mIU} / \mathrm{ml} \dagger$ & 1539 & 1644 \\
\hline
\end{tabular}

* GMC and standard deviation (sd) expressed as natural Logs

$\dagger \mathrm{GMC}$ expressed in milli international units per millilitre, resulting from back transformation of Logs

\section{Scatter plots of EIA by PRN values}

Fig. 1 shows the skewness of the antibody levels and improvement after log transformation. Log transformed levels of measles IgG by EIA or PRN spread around the equality line (Fig. 1) in maternal and umbilical cord sera, suggesting a reasonable agreement between the two methods.

\section{Scatter plots of the differences between the two methods (EIA-PRN) against the average of the two measurements}

When results for individual sera were plotted without transformation, Fig. 2a shows that the disagreement between the two methods in either direction could be as much as $10000 \mathrm{mIU} / \mathrm{ml}$ (or even more for the outliers). Log transformed values were plotted 
GONÇALVES, G.; CUTTS, F.; FORSEY, T. \& ANDRADE, H.R. - Comparison of a commercial enzyme immunoassay with plaque reduction neutralization for maternal and infant measles antibody measurement. Rev. Inst. Med. trop. S. Paulo, 41 (1): 21-26, 1999.
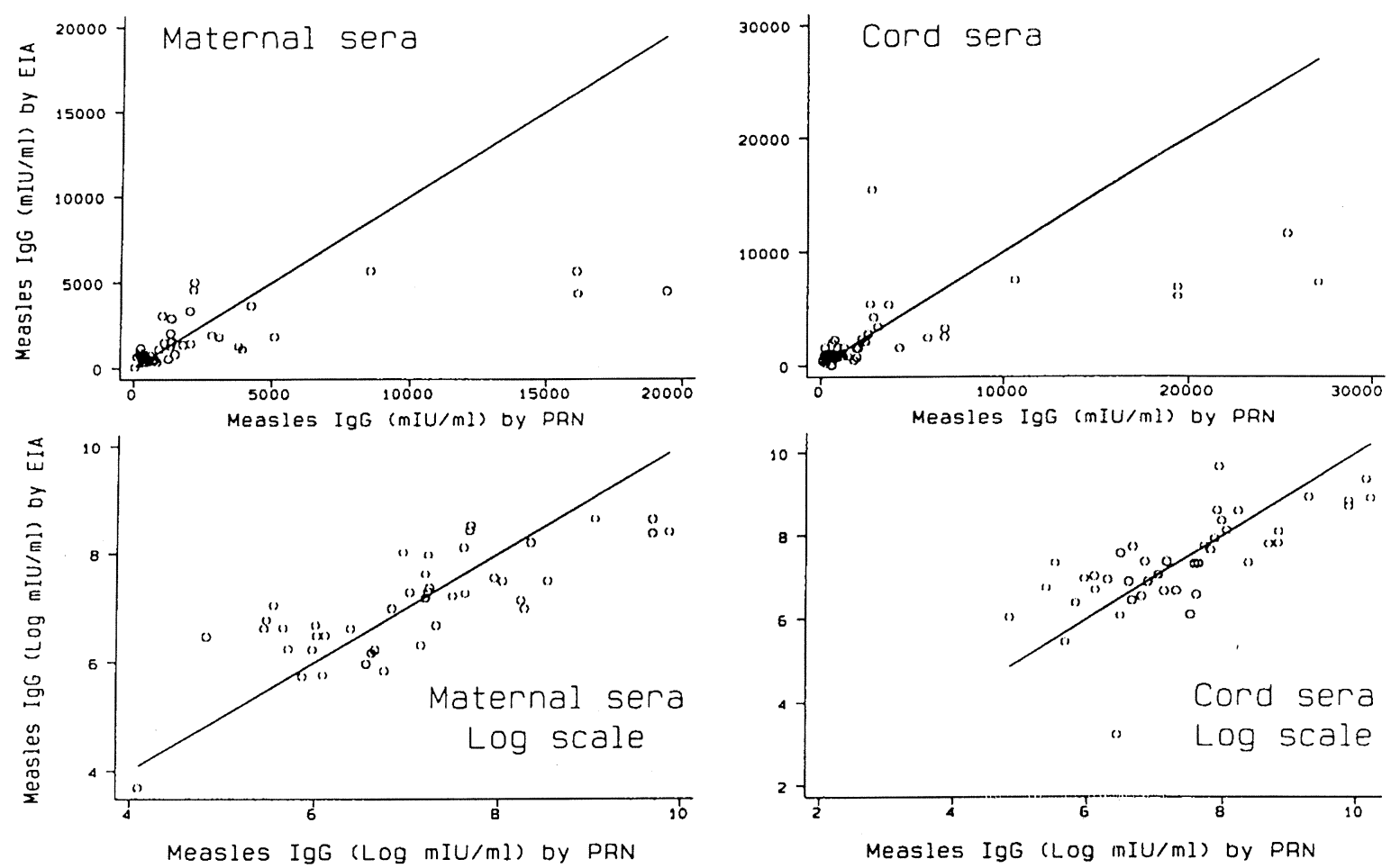

Fig. 1 - Comparison of EIA and PRN methods of measurement of measles IgG levels in maternal and umbilical cord sera ( $\mathrm{n}=43$ ), showing the equality lines.

2a
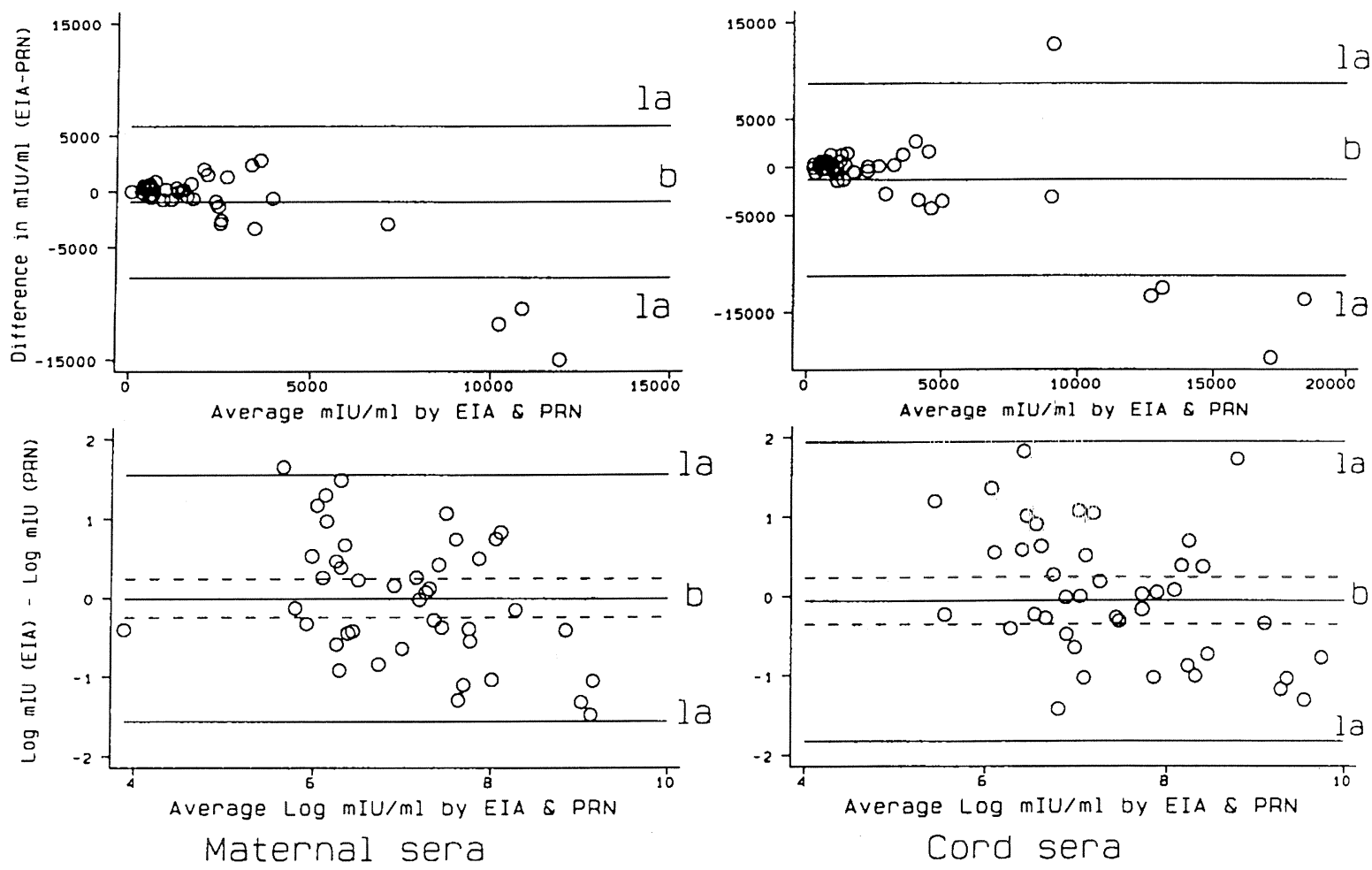

Fig. 2 - Differences between EIA and PRN measurements of measles IgG levels in maternal and umbilical cord sera. Arithmetic (Fig. 2a) and log (Fig. 2b) scales ( $\mathrm{n}=43$ ). The $95 \%$ CI limits of agreement (la) for individual differences, between EIA and PRN measurements of measles IgG, are shown. The bias (b) and the $95 \%$ CI limits (dashed lines) of the bias are also represented. 
GONÇALVES, G.; CUTTS, F.; FORSEY, T. \& ANDRADE, H.R. - Comparison of a commercial enzyme immunoassay with plaque reduction neutralization for maternal and infant measles antibody measurement. Rev. Inst. Med. trop. S. Paulo, 41 (1): 21-26, 1999.

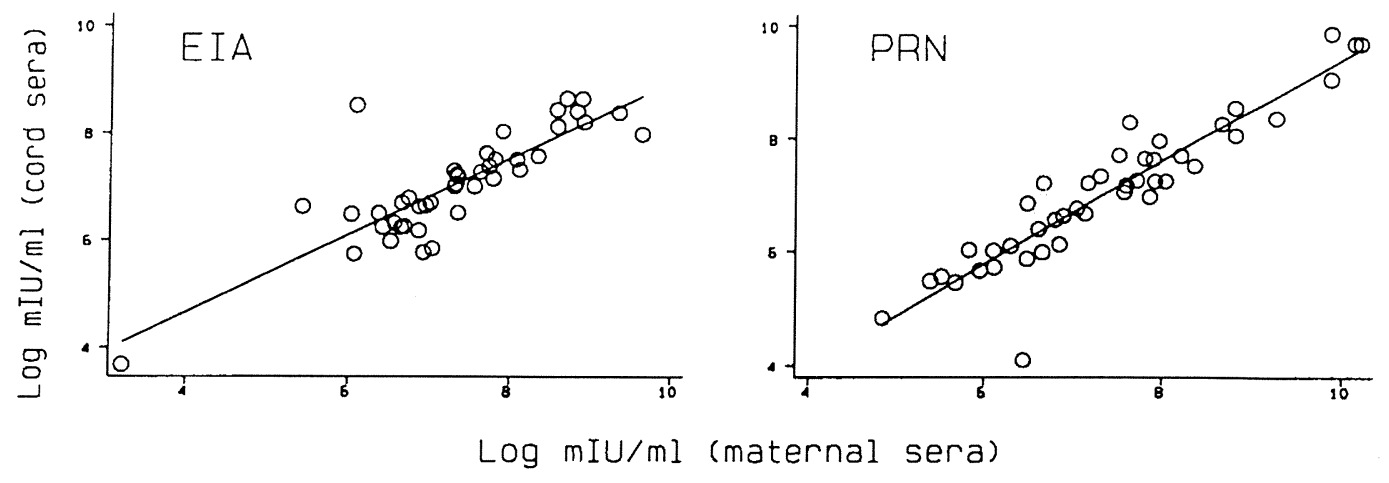

Fig. 3 - Regression lines of umbilical cord on maternal levels of measles IgG using EIA and PRN methods $(n=43)$.

Slope for EIA: 0.9766, correlation coefficient (r): 0.83

Slope for PRN: 0.9477 , correlation coefficient (r): 0.93

in Fig. 2b, which shows the $95 \%$ limits of agreement, and the limits of the $95 \% \mathrm{CIs}$ (dotted lines) of the bias, for both maternal and umbilical cord sera.

In the case of maternal sera, EIA produced individual estimates of measles IgG levels ( $\mathrm{mIU} / \mathrm{ml}$ ) between 0.21 to 4.70 times the results from PRN (taking the antilog of the limits of agreement shown in Fig. 2). For umbilical cord sera, the corresponding range of proportional agreement between the two methods, was 0.14-6.16. For maternal sera, mean EIA measurements had a proportional bias of 0.99 (95\% CI: 0.78 to 1.27 ) (Fig. 2b) times the results of mean PRN measurements; for umbilical cord sera, the proportional bias was 0.94 (95\% CI: 0.70 to 1.26) (Fig. 2b); in both instances the proportional bias was not significantly different from unity. In other words, though the differences of individual measurements may have a wide variation in both directions, the mean of the differences (bias) between the two methods is very close to 0 and the $95 \%$ CIs very narrow (Fig. 2), showing that differences between measurements performed by the two methods are very likely due to chance.

\section{Analysis of transplacental transport of measles IgG}

As Fig. 3 shows, the method of antibody measurement did not influence the model relating umbilical cord with maternal IgG levels. The slopes of the two models were parallel and intercepts were not different. There was no significant difference in transplacental concentration ratios computed from EIA values $(1.57 ; 95 \% \mathrm{CI}: 1.30$, $1.84)$ or from PRN values $(1.67 ; 95 \%$ CI: $1.21,2.12)$.

\section{Sera from infants}

In all sera of infants with undetectable measles IgG by PRN, EIA detected antibody, with concentrations ranging from 5 to 44 $\mathrm{mIU} / \mathrm{ml}$. However, if we consider as "positive" those sera with $\geq 40$

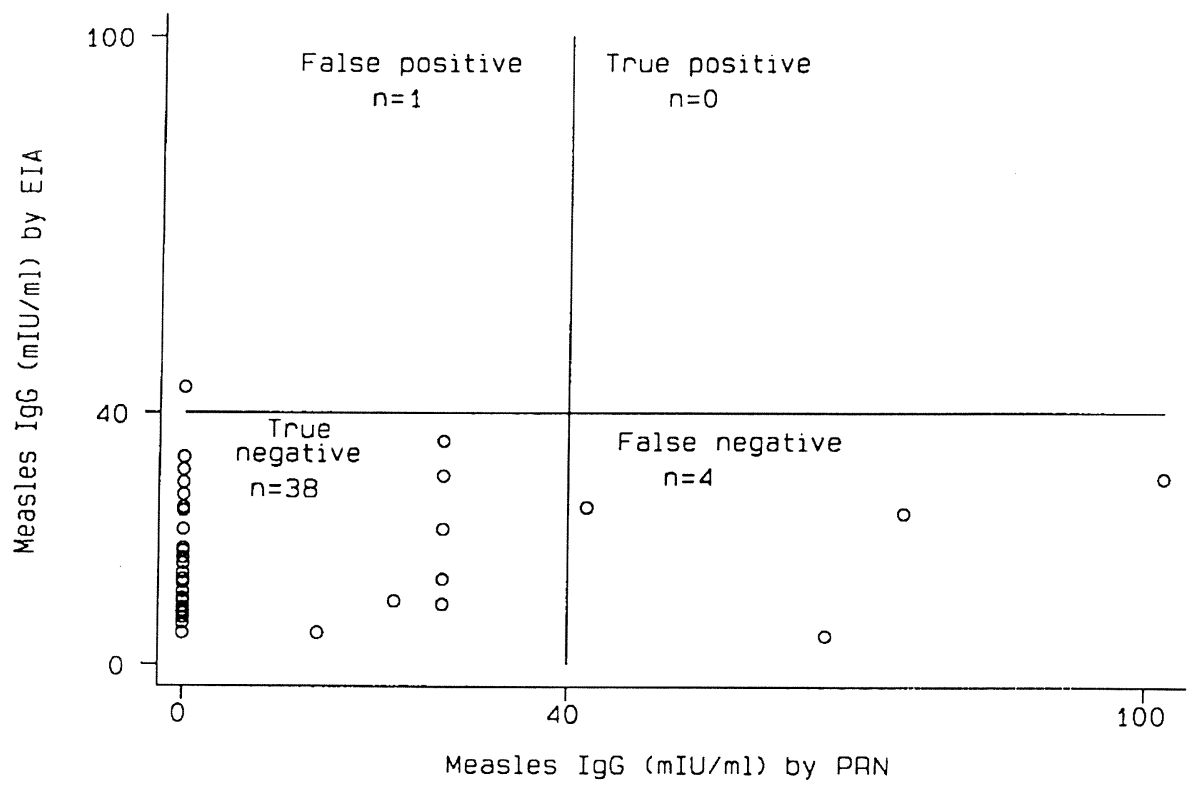

Fig. 4 - Comparison of measles IgG values by EIA or PRN, using the cut-off value of $40 \mathrm{mIU} / \mathrm{ml}$. Sera from 43 infants. 
GONÇALVES, G.; CUTTS, F.; FORSEY, T. \& ANDRADE, H.R. - Comparison of a commercial enzyme immunoassay with plaque reduction neutralization for maternal and infant measles antibody measurement. Rev. Inst. Med. trop. S. Paulo, 41 (1): 21-26, 1999.

$\mathrm{mIU} / \mathrm{ml}$ and "negative" those with $<40 \mathrm{mIU} / \mathrm{ml}$ (Fig. 4) $)^{14,25}$ the specificity of EIA compared to PRN was $97 \%$ (38 of 39 sera correctly identified as negative). All 4 samples with PRN values $\geq 40 \mathrm{mIU} /$ $\mathrm{ml}$, were negative by EIA. If the cut-off value used is $100 \mathrm{mIU} / \mathrm{ml}$, then the two methods only disagreed in one of the measurements, in which one serum had over $100 \mathrm{mIU} / \mathrm{ml}$ by PRN only.

\section{DISCUSSION AND CONCLUSIONS}

For maternal and umbilical cord sera, the two methods had a good proportional agreement. Though the geometric mean levels by EIA were slightly lower than those by PRN, the differences were not statistically significant. Nevertheless, for some individual sera, especially those with very high levels of $\mathrm{mIgG}$, the differences in absolute value of $\mathrm{mIU} / \mathrm{ml}$ might be large. If EIA were to be used, for example, to assess the need for (re)vaccination of an individual, this difference could have clinical importance. However, for the more common use of assessing immunity to measles at the population level, EIA would give valid results. In addition, for our original purpose, the use of EIA did not bias the analysis of transplacental transport of measles IgG (Fig. 3). In populations where a high proportion of individuals had vaccine-induced immunity, with lower antibody levels than those following natural infection, the correlation between EIA and PRN might, however, differ from that in our study.

For studies of passive immunity in infants, our results support previous findings that EIA does not correlate well with $\mathrm{PRN}^{15,28}$, although the numbers in our study were very small. Using a cut-off of $40 \mathrm{mIU}, 4$ of 43 sera gave false negative results by EIA. Hence, basing a decision on the optimum age for vaccination on results from EIA could lead to vaccination too early. Similarly, data from Kinshasa, Zaire, showed that in one study of 6 month old infants, only $2 \%$ were seropositive by a relatively insensitive commercial EIA assay ${ }^{12}$, whereas in a study in a similar population in Kinshasa, around $60 \%$ of 6 month old infants had antibody levels over $50 \mathrm{mIU}$ by PRN (F.Cutts unpublished data 1994). Thus, PRN remains the method of choice in studies of maternal measles antibody. For largescale studies of measles immunity in adults, the more practical EIA assay will usually suffice.

\section{RESUMO}

\section{Comparação de uma técnica imunoenzimática comercial com a redução de neutralização em placa, usadas no doseamento de IgG anti-sarampo em soros maternos e dos respectivos filhos}

A técnica de doseamento imunoenzimático (ELISA) de IgG antisarampo (IgG-AS) é a mais prática e conveniente para estudos com muitos soros. A técnica de referência é a redução de neutralização em placa (RNP). Para avaliar a concordância dos resultados obtidos por ELISA e pela técnica padrão RNP, comparámos os resultados de doseamentos efectuados pelas duas técnicas em 43 pares de soros de puérperas e respectivos recém-nascidos (cordão umbilical), e ainda nos soros dessas crianças em amostras colhidas entre os 11 e os 14 meses de idade. Nos soros maternos e do cordão umbilical, as diferenças médias das concentrações de IgG-AS medidas por ELISA ou RNP não eram estatisticamente significativas. No entanto, a nível individual as diferenças eram por vezes grandes. A concordância não era tão boa no caso dos soros infantis, nos quais os níveis de anticorpos residuais eram muito baixos. As conclusões de um estudo sobre transporte placentar de IgG-AS não seriam afectadas pelo uso de uma ou outra técnica. No entanto, nos estudos de imunidade residual no $1^{\circ}$ ano de vida, a RNP deveria ser a técnica escolhida, enquanto os resultados de estudos usando ELISA deveriam ser interpretados com cautela.

\section{ACKNOWLEDGEMENTS}

We are grateful to the women who agreed to participate in this study, to the heads of the Obstetric and Paediatric Departments of Maternidade Júlio Dinis, in Oporto, Portugal, and their staff for the collaboration in the study. We are especially grateful to Dr Rogério Mendes and the nurse Cecília for their involvement in the follow-up of the infants. The authors would also like to thank Professor J.C. Maia for his work with the Computer Programme to fit logistic curves. Part of this study was financed by Health Ministry (Portugal) and Junta Nacional de Investigação Científica e Tecnológica, through the programme "Programa Base de Investigação Científica e Tecnológica", project number PBIC/T/SAU/1522/92.

\section{REFERENCES}

1. ALBRECHT, P.; HERRMANN, K. \& BURNS, G.R. - Role of virus strain in conventional and enhanced measles plaque neutralization test. J. virol. Meth., 3: 251-260, 1981 .

2. ALTMAN, D.G. \& BLAND, J.M. - Measurement in medicine: the analysis of method comparison studies. Statistician, 32: 307-317, 1983.

3. ALTMAN, D.G. - Practical statistics for medical research. London, Chapman \& Hall, 1991.

4. BLACK, F.L. - Measles active and passive immunity in a world wide perspective. Prog. med. Virol. , 36: 1-33, 1989

5. BLAND, J.M. \& ALTMAN, D.G. - Statistical methods for assessing agreement between two methods of clinical measurement. Lancet, 1: 307-310, 1986.

6. BLAND, J.M. \& ALTMAN, D.G. - Comparing two methods of clinical measurement. Int. J. Epidem., 24(suppl.1): S7-S14, 1995.

7. BLAND, J.M. \& ALTMAN, D.G. - Comparing methods of measurement: why plotting difference against standard method is misleading. Lancet, 346: 1085-1087, 1995.

8. BRUGHA, R.; RAMSAY, M.; FORSEY, T. \& BROWN, D. - A study of maternally derived measles antibody in infants born to naturally infected and vaccinated women. Epidem. Infect., 117: 519-524, 1996.

9. CHEN, R.T.; MARKOWITZ, L.E.; ALBRECHT, P. et al. - Measles antibody; reevaluation of protective titers. J. infect. Dis., 162: 1036-1042, 1990.

10. CHRISTENSON, B. \& BOTTIGER, M. - Methods for screening the naturally acquired and vaccine-induced immunity to the measles virus. Biologicals, 18: $207-211,1990$. 
GONÇALVES, G.; CUTTS, F; FORSEY, T. \& ANDRADE, H.R. - Comparison of a commercial enzyme immunoassay with plaque reduction neutralization for maternal and infant measles antibody measurement. Rev. Inst. Med. trop. S. Paulo, 41 (1): 21-26, 1999.

11. CUTTS, F.T. - The immunological basis for immunization. Module 7: Measles. Geneva, World Health Organization, 1993. (WHP/EPI/GEN/ 93.17)

12. CUTTS, F.T.; MANDALA, K.; ST. LOUIS, M. et al. - Immunogenicity of hightitre Edmonston-Zagreb measles vaccine in human immunodeficiency virus-infected children in Kinshasa, Zaire. J. infect. Dis., 167: 1418$1421,1993$.

13. CUTTS, F.T. \& BROWN, D.W.G. - The contribution of field tests to measles surveillance and control: a review of available methods. Rev. Med. Virol., 5: $35-40,1995$

14. DABIS, F.; WALDMAN, R.J.; MANN, G.F. et al. - Loss of maternal measles antibody during infancy in an African city. Int. J. Epidem., 18: 264-268, 1989

15. DE FRANCISCO, A.; HALL, A.J.; UNICOMB, L. et al. - Maternal measles antibody decay in rural Bangladeshi infants: implications for vaccination schedules. Vaccine, 16: 564-568 1998.

16. DEAN, A.G.; DEAN, J.A.; COULOMBIER, D. et al. - Epi Info, Version 6: a word processing, database, and statistics program for epidemiology on microcomputers. Atlanta, Centers for Disease Control and Prevention, 1994.

17. FORSEY, T.; HEATH, A.B. \& MINOR, P.D. - The 1 st international standard for anti-measles serum. Biologicals, 19: 237-241, 1991.

18. GILL, J.S.; ZEZULKA, A.V.; BEEVERS, D.G. \& DAVIES, P. - Relationship between initial blood pressure and its fall with treatment. Lancet, 1: 567 $569,1985$.

19. GONÇALVES G. - Passive immunity against measles. London 1996. (PhD Thesis - University of London).

20. GUSTAFSON, T.L.; LiEVENS, A.W.; BRUNELl, P.A. et al. - Measles outbreak in a fully immunized secondary school population. New Engl. J. Med., 316: 771-774, 1987

21. HESKETH, L.; CHARLETT, A.; FARRINGTON, P. et al. - An evaluation of nine commercial EIA kits for the detection of measles specific IgG. J. virol. Meth., 66: 51-59, 1997
22. KIEPIELA, P.; COOVADIA, H.M.; LOENING, W.E.K.; COWARD, P. \& ABDOOL KARIM, S.S. - Loss of maternal measles antibody in black South African infants in the first year of life - implications for age of vaccination. $S$. Afr. med. J., 79: 145-148, 1991.

23. KLEINBAUM, D.G.; KUPPER, L.L. \& MULLER, K.E. - Applied regression analysis and other multivariable methods. 2. ed. Boston, PWS-KENT Publishing, 1988.

24. MANN, G.F.; ALLISON, L.M.C.; COPELAND, J.A.; AGOSTINI, C.F.M. \& ZUCKERMAN, A.J. - A simplified plaque assay system for measles virus. J. biol. Stand., 18: 219-225, 1980.

25. MARKOWITZ, L.E.; SEPULVEDA, J.; DIAZ-ORTEGA, J.L. et al. - Immunization of six-month-old infants with different doses of Edmonston-Zagreb and Schwarz measles vaccines. New Engl. J. Med., 322: 580-587, 1990.

26. NEUMANN, P.W.; WEBER, J.M.; JESSAMINE, A.G. et al. - Comparison of measles anti-hemolysin test, enzyme linked immunosorbent assay, and hemagglutination inhibition test with neutralization test for determination of immune status. J. clin. Microbiol., 22: 296-298, 1985.

27. RATNAM, S.; GADAG, V.; WEST, R. et al. - Comparison of commercial enzyme immunoassay kits with plaque reduction neutralization test for detection of measles virus antibody. J. clin. Microbiol., 33: 811-815, 1995.

28. SABIN, A.B ; ARECHIGA, A.F.; CASTRO, J.F. et al. - Successfu immunization of children with and without maternal antibody by aerosolized measles vaccine: I. Different results with undiluted human diploid cell and chick embryo fibroblast vaccines. J. Amer. med. Ass., 249: 2651 2662,1983

29. SABIN, A. B.; ARECHIGA, A.F.; CASTRO, J.F. et al. - Successful immunization of children with and without maternal antibody by aerosolized measles vaccine: II. Vaccine comparisons and evidence for multiple antibody response. J. Amer. med. Ass., 251: 2363-2371, 1984.

30. SOUZA, V.A.U.F.; PANNUTI, C.S.; SUMITA, L.M. \& ALBRECHT, P. - Enzyme linked immunoabsorbent assay (ELISA) for measles antibody. A comparison with haemagglutination inhibition, immunofluorescence and plaque neutralization tests. Rev. Inst. Med. trop. S. Paulo, 33: 32-36, 1991.

31. WEIGLE, K.A.; MURPHY, M.D. \& BRUNELL, P.A. - Enzyme linked immunosorbent assay for evaluation of immunity to measles virus. J. clin. Microbiol., 19: 376-379, 1984

Received: 08 June 1998

Accepted: 10 December 1998 